\title{
Economic feasibility of hay enriched extruded production as a complete diet for equine
}

\author{
Viabilidade econômica da produção de feno enriquecido extrusado como dieta completa \\ para equinos
}

\author{
Kátia FELTRE'; Mayara Angela Faga PALAGI ${ }^{1}$; Augusto Hauber GAMEIROํㅜ ; Henry WAJNSZTEJN ${ }^{2}$ \\ Alexandre Augusto de Oliveira GOBESSO ${ }^{1}$ \\ ${ }^{1}$ Universidade de São Paulo, Faculdade de Medicina Veterinária e Zootecnia, Departamento de Nutrição e Produção Animal, \\ Pirassununga - São Paulo, Brazil \\ ${ }^{2}$ Faculdade de Ciências Biomédicas, Cacoal - Rondônia, Brazil
}

\begin{abstract}
The present study aimed to evaluate the economic feasibility of production and commercialization project of Hay Enriched Extruded (HEE) as a complete diet for horses. The study was based on survey data and quotation activities involving price from the land preparation (repair, planting and fertilization) to the processing of the product at the factory (extrusion) and marketing. Transportation costs and taxes were also considered. Discounted Cash Flow (30 years) was used to calculate the profitability indicator and the Profit and Loss Statement (PLS). Calculations were developed using Microsoft Office Excel ${ }^{\circledR}$ spreadsheets. Three production scenarios were simulated with different consumer prices: Scenario 1 - equivalent to the complete diet, where the ingredients are supplied together, but purchased separately; Scenario 2 - Considering a value $10 \%$ higher than the complete diet; Scenario 3 - Considering a value $20 \%$ higher than the complete diet. We observed that the project was economically viable in the three suggested scenarios with positive Net Present Value, Internal Rate of Return greater than $9.4 \%$ and payback of 11 to 2 years. The results enable us to conclude that the product may be a promising investment for both product quality and ease of use as the rapid return on invested capital.
\end{abstract}

Keywords: Horses. Economy. Extrusion. Nutrition.

\section{Resumo}

O presente estudo objetivou avaliar a viabilidade econômica de um projeto de produção e comercialização do Feno Enriquecido Extrusado (FEE) como dieta completa para equinos. O estudo baseou-se em levantamento de dados e cotação de preços de atividades que envolvem desde o preparo da terra (correção, plantio e adubação) até o beneficiamento do produto na fábrica (extrusão) e comercialização. Foram considerados também os custos com transporte e tributações. Para o cálculo dos indicadores de rentabilidade utilizou-se o método do Fluxo de Caixa Descontado (período de 30 anos) e da Demonstração de Resultados do Exercício (DRE). Os cálculos foram desenvolvidos utilizando planilhas eletrônicas do pacote Microsoft Office Excel ${ }^{\circledR}$. Foram simulados três cenários de produção com diferentes preços ao consumidor: Cenário 1) equivalente à dieta completa, onde os ingredientes são fornecidos em conjunto, mas adquiridos separadamente; Cenário 2) considerando um valor $10 \%$ maior que o da dieta completa; Cenário 3) considerando um valor $20 \%$ maior que o da dieta completa. Pôde-se observar que o projeto foi viável economicamente nos três cenários sugeridos com Valor Presente Líquido (VPL) positivo, Taxa Interna de Retorno (TIR) maior que 9,4\% aa e payback de 11 a 2 anos. A produção de FEE pode ser um investimento promissor tanto pela qualidade do produto e facilidade de uso quanto pelo rápido retorno do capital investido.

Palavras-chave: Cavalos. Economia. Extrusão. Nutrição.

Correspondence to:

Kátia Feltre

Universidade de São Paulo, Faculdade de Medicina Veterinária e Zootecnia, Departamento de Nutrição e Produção Animal

Avenida Duque Caxias Norte, 225

CEP 13635-000, Pirassununga, SP, Brazil

e-mail: katiafeltre@usp.br

Received: 25/03/2015

Approved: 26/02/2016 


\section{Introduction}

The massive portion of foods used in the nutritional management of horses besides occupying important position in the economic scenario of the properties shows remarkable variation in prices during the year due to strong seasonality of production in Brazil. Moreover, transportation costs, the need for storage facilities, waste generated during the supply of roughage into stalls and the need for cutting and providing green grass in dry seasons, has led researchers to develop alternatives to bypass these disadvantages, facilitating the handling of horses as well as reducing production costs.

Thus the use of complete feeds that feature all the balanced nutrients and ensure the maintenance of animal health while optimizing the power supply, protein and fiber, requires greater understanding of the effects of variation in the physical form of feed. The daily consumption of correct portions of forages and concentrated feed play an important role in the nutrition of horses. Variations can cause significant changes in the gastrointestinal ecosystem, and consequently, produce physiological changes in animals (MIRAGLIA et al., 2006).

The animal feed industry is quite significant in Brazil and worldwide. In 2010, according to the International Feed Industry Federation (IFIF), Brazil ranked as the fourth largest producer of feed, surpassed only by the United States, European Union and China, accountable for about $70 \%$ of world production (IFIF, 2011). According to data from producers of feed companies associated with the Sindirações, in 2012, 63 million tons of rations were produced, and $1 \%$ of production was intended for horses (SINDIRAÇÕES, 2012).

Thus, the improvement of processes involving the feed industry (production, processing and logistics of ingredients) and the processes that directly involve the factories (among them heat treatments of the ingredients, such as pelletizing) can positively influence the nutritional management as well as favoring the production costs with satisfactory economic results in the breeding of horses.

The production of a complete feed technology emerges as a very interesting alternative, because this is a practical and flexible dietary use, which is independent of seasonal production. However, there is no information in the literature about the use of this type of feed in horse nutrition referring to the economic viability of production.

Therefore, this study aimed to evaluate the economic feasibility of a production and commercialization project of Hay Enriched Extruded (HEE) as a complete diet for the equine species.

\section{Materials and Methods}

A rural property of 114 hectares of arable land located in Pirassununga (SP) in 2013 was adopted as a reference for this project. In relation to the agricultural costs, soil analysis and simulations were conducted to evaluate the chemical and physical characteristics as a basis for estimating the costs of fertilization and acidity correction of the area to be planted. Agricultural operations of soil preparation, use of pesticides and fertilizers (for planting and topdressing) and equipment necessary for the production of hay (baler, mowing, rotary rakes, etc.) were considered.

To raise the product processing costs, industrial equipment, the necessary ingredients, the energy costs in the region, the manpower, and the bagging and packaging value were considered. A distance of distribution within a radius of $300 \mathrm{~km}$ was considered for the transport costs.

Calculation of the profitability indicators involved using the Discounted Cash Flow (30 years) and the Profit and Loss Statement (PLS) methods, based on Martins (1990). All current prices of inputs and services were raised in the 2013 year at the regional market of Pirassununga through phone calls, visits to establishments or quotes via internet. The calculations were developed using Microsoft Office Excel ${ }^{\triangleright}$ spreadsheets. 
The legal requirements involved in the production and commercialization of the product were investigated. The regulation related to the production of animal feed was obtained in the Official Gazette database. The incidence of various taxes (federal, state and local), their respective rates and collection forms were requested from the advice of a specialized accounting office (SENSO, 2008).

The spreadsheets that were the basis for this study considered the following economic parameters: assets (real estate, equipment, vehicles), personal (operational and administrative), inputs (agricultural and industrial), expenses (operational and administrative), production planning (volume, price etc.), nutritional equivalence (complete diet), taxation (municipal, state and federal), transport (up consumer market), the Income Statement (monthly) cash flow (annual, for 30 years).

Three scenarios based on different selling prices of HEE to the final consumer (horse breeder) were elaborated. To reach that final selling price, we considered the equivalent cost to the complete diet composed of the ingredients needed to manufacture the same purchased separately (commercial concentrate, mineral salt, common salt and hay). The retail value of the HEE considered for the first scenario was $\mathrm{R} \$ 1.09 / \mathrm{kg}$. Due to the convenience of handling the HEE, for scenarios 2 and 3, we considered an additional $10 \%$ and $20 \%$, respectively, compared to the price of the base scenario. Thus, HEE of sales prices for scenarios two and three were $\mathrm{R} \$$ $1.21 / \mathrm{kg}$ and $\mathrm{R} \$ 1.30 / \mathrm{kg}$, respectively.

In terms of sale volume, a captive market related to the consumption of only HEE to 1,125 animals/year was considered, in addition to commercial distribution of the same by a representative that would receive a gross margin of $25 \%$.

In the spreadsheet cash flow, revenues and expenses during the horizon project of 30 years were estimated. For this investment, we considered an interest rate of $2.4912 \%$ per year. This might represent the real interest rate for the Brazilian economy in 2013. It was calculated considering two data. The first was the average nominal interest rate known as "Selic" (the basic interest rate paid by the federal government to bonds he issues in the market to raise funds), which was equal to $8.1925 \%$ per year. The second was the cumulative inflation rate in the year (represented by the National Consumer Prices Index, INPC/IBGE), which was equal to $5.5627 \%$.

To assess the feasibility of production of the HEE, other indicators of financial performance such as the Net Present Value (NPV), Internal Rate of Return (IRR) and the simple pay-back were also used.

A sensitivity analysis was performed to identify the item or items that may affect the economic results of a system and influence the financial viability of the activity. Through this analysis it is possible to determine to what extent the change in one variable focuses on system results providing a more rigorous assessment which generates a more precise interpretation of the risks associated with the activity (JERÔNIMO, 2013), allowing the farmer to know that future errors can result in great economic losses.

\section{Results and Discussion}

Using as financial profitability indicators Net Present Value (NPV), Internal Rate of Return (IRR) and the simple pay-back, the project was observed to be economically viable in the three suggested scenarios as shown in table 1 .

The economic profitability indicators generally used in financial analysis are the NPV and IRR. The NPV is considered a more rigorous evaluation criterion and free from technical faults (NORONHA, 1987). The activity is viable to present a positive NPV. The IRR, defined by Contador (1988), is the discount rate that equates the present value of benefits to the present value of the costs of a production system, that is, equals zero. A system is viable when its IRR is equal to or greater than the cost of capital opportunity. Based on this information and observing the three scenarios suggested, all scenarios were economically viable, showing that the project will 
cover both the initial investment and the minimum remuneration required by the investor, generating even greater financial surplus compared to scenarios 1 and 2. The comparison between the scenarios shows that the financial indicators are highly sensitive to the price established for the final product (HEE).

Table 1 - Analysis of the economic feasibility of production of Hay Enriched Extruded (HEE) as complete diet for horses - Pirassununga - 2013

\begin{tabular}{lccc}
\hline \multicolumn{1}{c}{ Indicator } & Scenario 1 $^{\mathbf{a}}$ & Scenario 2 $^{\mathbf{b}}$ & Scenario 3 $^{\mathbf{c}}$ \\
\hline Investment $(\mathrm{R} \$)$ & $1,035,352.76$ & $1,035,352.76$ & $1,035,352.76$ \\
Selling price of HEE $(\mathrm{R} \$ / \mathrm{kg})$ & 0.78 & 0.87 & 0.96 \\
HEE price to the farmer $(\mathrm{R} \$ / \mathrm{kg})$ & 1.09 & 1.20 & 1.31 \\
Gross revenue $(\mathrm{R} \$$ mouth) & $240,240.00$ & $267,960.00$ & $295,680.00$ \\
Average monthly net income $^{\mathrm{d}}(\mathrm{R} \$ /$ mouth) & $36,517.24$ & $45,487.19$ & $54,457.13$ \\
Internal Rate of Return $\left.^{\mathrm{e}} \% \mathrm{aa}\right)$ & 9.44 & 38.39 & 66.30 \\
Simple Payback (years) $_{\text {Net Present Value }^{\mathrm{e}}(\mathrm{R} \$)}^{11}$ & 3 & 2 \\
\hline
\end{tabular}

${ }^{\mathrm{a}}$ Complete diet equivalent to diets using ingredients supplied together, but separately acquired; ${ }^{\mathrm{b}}$ Considering a value $10 \%$ higher than the complete diet; ${ }^{\mathrm{c}}$ Considering a value $20 \%$ higher than the complete diet; ${ }^{\mathrm{d}}$ Remuneration of the entrepreneur's work not discounted; ${ }^{3}$ For a 30 -year period

The economic profitability indicators generally used in financial analysis are the NPV and IRR. The NPV is considered a more rigorous evaluation criterion and free from technical faults (NORONHA, 1987). The activity is viable to present a positive NPV. The IRR, defined by Contador (1988), is the discount rate that equates the present value of benefits to the present value of the costs of a production system, that is, equals zero. A system is viable when its IRR is equal to or greater than the cost of capital opportunity. Based on this information and observing the three scenarios suggested, all scenarios were economically viable, showing that the project will cover both the initial investment and the minimum remuneration required by the investor, generating even greater financial surplus compared to scenarios 1 and 2. The comparison between the scenarios shows that the financial indicators are highly sensitive to the price established for the final product (HEE).
For the realization of sensitivity analysis, the items that make up the cash flows of each system can be studied individually. According to Lima et al. (2007), the basic procedure to make a sensitivity analysis is to choose the indicator to raise awareness, determine its expression depending on the chosen parameters and variables.

Considering the first scenario as an example, the results of the sensitivity analysis are shown in figure 1. In this project, inputs directly influenced the project budget, representing $78.7 \%$ of the costs and occupying the first place in the sensitivity analysis, followed by personal items (6.8\%), depreciation (4.7\%), general operating expenses (3.2\%) and maintenance $(0.8 \%)$.

Based on the results obtained it can be concluded that the production of Hay Enriched Extruded is economically viable and can be a promising investment both for product quality and ease of use as a rapid return on invested capital. 


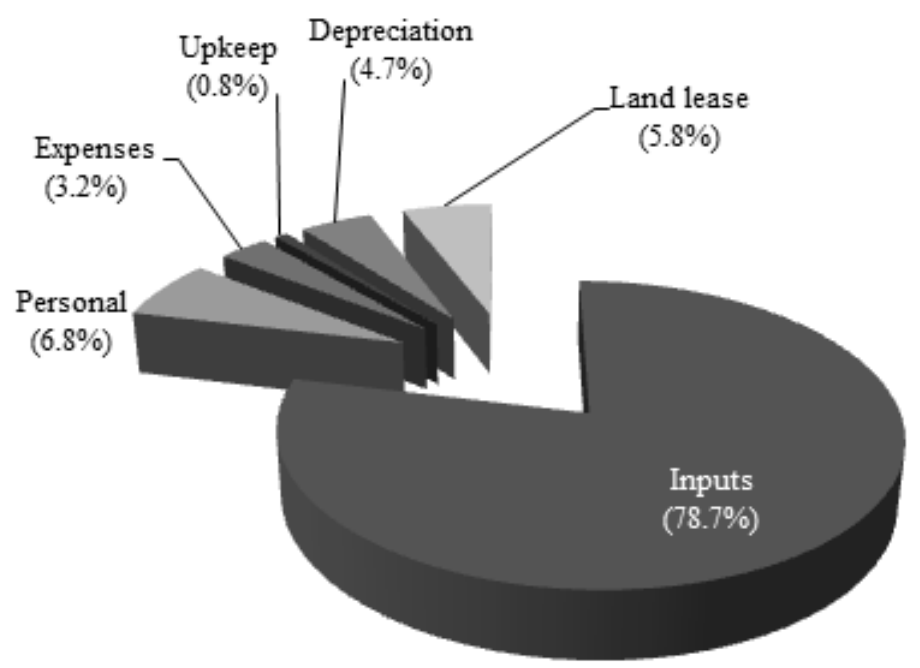

Figure 1 - Sensitivity analysis results of Hay Enriched Extruded (HEE) considering the scenario 1 where the complete diet is equivalent to diets using ingredients supplied together, but separately acquired. Spreadsheet analysis of the costs of services / products sold

\section{References}

CONTADOR, C. R. Indicadores para seleção de projetos. In: CONTADOR, C. (Ed.) Avaliação social de projetos. 2. ed. São Paulo: Atlas, 1988. p. 41-58.

\section{INTERNATIONAL FEED INDUSTRY FEDERATION} (IFIF). Annual report. 2011. Available from: <http://www.ifif.org/>. Viewed: 25 May 2013.

JERÔNIMO, C. E. M. Estudo de viabilidade econômica aplicado a um projeto agroindustrial: analise de sensibilidade. Revista de Administração de Roraima, v. 3, n. 2, p. 156-180, 2013. doi: http://dx.doi.org/10.18227/rarr.v3i2.790.

LIMA, E. A.; COELHO, F. C.; BASTIANI, M. L. R.; GOLYNSKI, A.; PONCIANO, N. J.; LIMA, A. A. Avaliação econômica e de risco da produção de soja em rotação com cana-de-açúcar na Região Norte Fluminense. Acta Scientiarum: Agronomy, v. 29, n. 3, p. 403-409, 2007. doi: http://dx.doi.org/10.4025/actasciagron.v29i3.392.

MARTINS, E. Contabilidade de custos. 4. ed. São Paulo: Atlas, $1990.311 \mathrm{p}$.
MIRAGLIA, N.; BERGERO, D.; POLIDORI, M.; PEIRETTI, P. G.; LADETTO, G. The effects of a new fibrerich concentrate on the digestibility of horse rations. Livestock Science, v. 100, n. 1, p. 10-13, 2006. doi: http://dx.doi.org/10.1016/j.livprodsci.2005.11.003.

NORONHA, J. F. Projetos agropecuários: administração financeira, orçamento e viabilidade econômica. 2. ed. São Paulo: Atlas, 1987. 269 p.

SENSO Assessoria Contábil. Comunicação Pessoal. São Paulo, 2008.

SINDIRAÇÕES. Boletim informativo do setor. 2012. Available from: <http://sindiracoes.org.br/>. Viewed: 25 May 2013. 